\title{
HISTORICAL EDITING AND RESEARCHING LOCAL HISTORY \\ IN AN UNDERGRADUATE BLACK STUDIES SEMINAR
}

\author{
Randall K. Burkett \\ College of the Holy Cross
}

Over the past four years I have taught a course on Black Religion in America in several different ways. Originally it was designed as a traditional lecture course which surveyed the history and development of the institutional churches from slavery to the present. Research projects were designed to give students a feel for the church by getting them out into the community to observe ritual patterns, analyze iconographic elements, and note the patterns of personal and social interaction.

Since I have been at the College of the Holy Cross, the focus and method have shifted. I have been able to offer the course on a seminar rather than a lecture format and to introduce various new research techniques to the students. The course has several objectives, both general and specific. With respect to the former, I want students to recognize that the academic study of religion is both interesting and integrally important. Religion, I insist to my students, not only has "functional" significance with respect to behavior patterns, social structure, and social change, but it also must be taken with the utmost seriousness as the lived and meaning-filled experience of individuals and groups. I encourage students to bracket their rush to judgment and to attempt to view a religious group so far as possible on its own terms, and from the perspective of the members to whom it provides a meaningful way of understanding the world.

With specific reference to Afro-American religious history, the nearly axiomatic remark is that "the Black Church is the single most influential institution developed in and by the Black community." However, in spite of an overwhelming amount of primary source material, the history of this institution is largely unwitten. I would like my students to gain a critical appreciation for the history and development of Afro-American religious institutions, and to understand the broader role of religion in the life of the Black community.

Given the state of the field, the question has been how best to approach the subject matter of the course. When the seminar was last taught, I decided to offer students the opportunity of making "local studies" the focus of the course and of their major research projects. (The plan for the lectures was to introduce appropriate background material where needed and to place student research projects in a broader context.) Local studies seemed an attractive idea for several reasons. In the first place, Worcester's Black community, though unusually small as compared with neighboring cities of Springfield, New Bedford, Hartford, Providence, and Boston, has also been remarkably stable. In 1920, for instance, the Black population of 1,258 constituted only seven tenths of one per cent of the total population. In the decade from 1910 to 1920 , which is marked by a dramatic increase in the Northern and urban migration of Black Americans, the Black population of Worcester increascd by only seventeen souls, from 1,241 to 1,258. This unusually stable pattern has continued well into the mid-twentieth century, and, in fact, the Black population has only recently begun to increase as a percentage of the total population. As far as prospects for my course were concerned, this stability of population meant that memories of some of the older Black residents were likely to go back a long way, making it possible for very useful oral history projects to be developed.

An earlier version of this paper was presented at the annual meeting of the Organization of American Historians, Atlanta, April 8, 1977. 
A second reason which made the "local studies" format attractive was that the city of Worcester has in its midst several Black churches of long standing. The African Methodist Episcopal Zion Church of Worcester, for instance, was founded as early as 1846, just a quarter of a century after the denomination 1tself was organized. An African Methodist Episcopal church was formed soon after the Civil War, and a Black Baptist church was organized in the $1880 \mathrm{~s}$. These were the first Black voluntary associations formed in Worcester, and I hoped that their archival records might provide valuable sources of information with which my students could work.

Finally, Holy Cross students, like most students wherever they attend college, tend to assume that there is no place in the world less interesting than the "backward" town in which their own academic institution happens to be located. I thought it might be possible to challenge that assumption by getting students involved with Worcester's history.

With a focus on "local studies," the eight seminar members were able to select any research topic that dealt with Black religious 11 fe in the city. Possible topics included studies in Black preaching, writing the history of a women's religious club or a particular congregation, and examining the social and political activities of a church. I was also able to include as one of the options an historical editing project. While doing research earlier in the Holy Cross archives, I had discovered that substantial correspondence, diaries, and other manuscripts of James A. Healy were retained by the college. Healy was the valedictorian of the first graduating class of Holy Cross in 1849. He later became bishop of the Diocese of Portland, Maine, while his brother Patrick, who graduated from Holy Cross in 1850, became president of Georgetown University. The Healys were Black, thelr mother bèing a slave who was owned by their father, Michael Healy, an Irish immigrant who settled in the late 1820s near Macon, Georgia. Mlchael took the slave woman Eliza as his wife in 1829, and had ten children by her. Four of those children went to Holy Cross for an education, and two of them were members of the first graduating class. (As my seminar researchers pointed out, fifty per cent of the graduating class of four was thereby Black, a percentage of "minority" students which the College has not attained in the years since.)

Among the voluminous Healy manuscripts possessed by the college, one of the most fascinating is Healy's diary for the year 1848-1849, his sentor year. Despite my best efforts, I could not convince the entire class to take as their project the editing of the diary, though two students did decide to work on 1t. Each selected consecutive two-week sections to transcribe and annotate, and each wrote an introductory essay analyzing Healy's life.

The other projects undertaken were the following:

"History of Worcester's Belmont Street A.M.E. Zion Church;"

"Rev. Wm. Kelley--A.M.E. Zion Pastor" (A Biographical Study);

"Black Preaching: An Experimental Approach to Analyzing the Negro Sermon;"

"From the Nation of Islam to the New World Community of Islam in the

West" (From the Perspective of the Worcester Mosque);

"Black Youth and Religion" (An Analysis of Youth Programs in Worcester B1ack Churches);

"John Street Baptist Church" (Political Voice in the Community). 
It was my hope that during the semester one of the results of all the projects would be to turn up substantial amounts of hitherto untapped primary resources. To a limited extent we succeeded, discovering, for instance, two very interesting publications which were edited by A.M.E. Zion clergymen during their pastorates in Worcester. One was a four-page newspaper entitled the Zion Trumpet, published during 1888 and 1889 by Eli George Biddle. William J. Walls's authoritative history of The African Methodist Episcopal Zion Church (1974) makes mention of Pastor Biddle's Zion Trumpet, which was eventually adopted as a connectional organ, but Walls incorrectly assumed that publication began only in 1889, after Biddle had moved to New Haven. One of the most interesting articles in the issues we located reported formation, in the Zion Church, of a Worcester Builder's Association. It was created, according to the Trumpet, because of "the unjust discrimination against us as a race that is characteristic of this and most all Northern cities, and which has at last compelled thinking men to unite in self-defense, so that at least their children may be delivered from the slurs and insults of the professedly Christian landlords of our city."

Scattered copies of a second publication from the A.M.E. Zion Church, the Zion Quill, were found at the Worcester Historical Society. The Quill was published by Rev. Frederick C. Van Buren, a pastor in Worcester during the early and mid-1920s. It was essentially a parish organ (as the masthead stated, it was "the only Afro-American Periodical Published in the County of Worcester"), and did not carry as much news about New England Zion Methodism as did the Trumpet. Nevertheless, a substantial amount of information could be garnered from its pages. We learned, for instance, of the visits of Mary White Ovington and Robert Bagnall to Worcester, to assist in founding an NAACP chapter. Births, deaths, and marriages for the entire Black community were apparently recorded there also.

The oral history projects were not as successful as I had originally hoped. One of the lessons I learned from this experfence is that it is very difficult for undergraduates to undertake and carry out oral history projects, unless extraordinary care is taken in the planning stage. I thought I had prepared students adequately for this assignment by requiring them to do extensive background reading for their topics, by encouraging them to become familiar with the equipment itself through mock interviews, and by insisting that they write down a series of questions which they planned to ask once in the interview situation. My limited experience suggests that it takes perseverance, poise, and practice to develop a successful oral history project, and, short of devoting a considerable portion of class time enabling students to acquire these skills, it is difficult for such projects to succeed.

The best projects undertaken in the seminar involved the editing of James Healy's diary. In the first place, this was a project with which students could identify personally: as Black students in an overwhelmingly white institution, they were immediately intrigued by the idea of delving into the Innermost thoughts of a Black man who had attended Holy Cross more than one hundred and twenty-five years ago.

Their first reaction to the diary itself. once the text was made available to them, however, was one of keen disappointment. Healy failed even once in over two hundred and twenty-five pages of writing to discuss the fact that he was a Negro, to reflect on the plight of slaves in the South, or to recount race-related incidents that had occurred in Worcester. (Healy was not. I should add, a-political. He frequently commented on the latest news reports from Europe, where major political upheavals were occurring; and he evinced considerable interest in the welfare of the Pope. who was forced to flee now 
to France, now to Italy, as events of the year unfolded.) But there was no mention in his diary, for instance, of the activities of Worcester abolitionists Abby Kelley and Stephen S. Foster. There was a single reference to use by one of his classmates of the epithet "nigger," and on one occasion he spok of reading "some interesting letters between a Northerner and a Southerner," in a newspaper sent by a friend.

Having overcome their initial disappointment, however, the students becan fascinated with the regimen of school life in the mid-1800s, with the currict ulum to which students were committed (Healy regularly discussed reading assignments or class debates or the merits of the morning chapel homily), and with the inevitable complaints about the absence of heat and intolerable food. They surprised themselves, I think, by how many of the dozens of names mentioned by Healy they were able to identify via the local archives or College histories.

They remained to the end most interested in Healy himself, as they tried to understand his apparent 1 ffe-long indifference to racial problems in either the antebellum or post-Civil War years, in spite of the fact that he was known throughout his career, both as a parish priest and later bishop, for having a special concern for children and for the poor. Beyond this, the students also became interested in and quite informed about the early history of the College of the Holy Cross.

Finally, and perhaps most importantly, they gained by the end of the project a considerable respect for the document with which they were working. On the one hand they wanted to record it faithfully as the author had written it and to provide as much annotation and information as they could unearth. On the other hand, they were astonished at the liberality with which various "interpreters" of James Healy's life had deduced judgments about the man which were presented as fact. That is to say, the students were beginning, by the end of the semester, to be critical historians, and this 1s something which they acquired primarily by editing and annotating a document.

There are a number of problems one may encounter in setting up a "local studies" seminar such as the one I have described. With respect to historical editing, the first task is to Identify and arrange permission to use a document or dlary for a research seminar. Certainly, in the case of the Healy diary, problems were greatly alleviated by virtue of the fact that the material was an "in house" document. I had no problem in securing permission from Holy Cross to copy the diary for my students, and I was able to supervise the duplication personally. The matter of securing documents from a local historlcal soclety can be much more difficult, as well as expensive. But great benefits can derive from an editing project once it is undertaken, the gains far offsetting the time and costs of organization.

Apart from the seminar setting, it would be most interesting to utilize editing in a freshman seminar or in an introductory history course, assuming that problems of class size can be overcome. Confronted by the "bare bones" of an unexplained document, students mlght begin at an earlier point in their academic careers critically to wonder at the elaborate interpretations with which these documents are clothed by the historians whom students too often tend to assume are just giving the "facts" as they "really happened." At any rate, on the basis of my experience, historical editing can have that very valuable result.

As far as the other projects are concerned, it should be evident that a great deal of groundwork is required in order to secure the cooperation of private institutions such as individual churches or private persons. 
Particularly with respect to the Black community, there is a long tradition of academic exploitation of the community as a "laboratory" for social scientific and other research. One must be genuinely convinced that there is an important piece of history worth preserving before attempting to approach such private institutions, if one is to avoid alienating further these groups from the college or university. And students must be cautioned that their task is not to teach or to criticize those community representatives who have agreed to cooperate with the program, but rather to learn about and possibly to assist in preserving a part of the story of the community which might otherwise be forgotten.

In conclusion, I would underscore the merits of "local studies" as the focus for an American history seminar, regardless of whether it will have an emphasis on ethnic history. However, there are special benefits to a local studies emphasis in a Black history course. My experience confirms my previous intuition: namely, that there are significant reservoirs of primary source materials which have been preserved within the Black community by older residents who know full well the value of the treasures they have retained, regardless of whether the local historical society, college, or public library believed them important. If we historians can merit their trust by conscientious effort and hard work, we may find the Black community eager to share their resources with us and with our students. 